\title{
CONCEPÇÃO DE VERDADE E FRACASSO ESCOLAR:
}

\section{UM DIÁLOGO POSSÍVEL ENTRE A FILOSOFIA DE MARTIN HEIDEGGER E A EDUCAÇÃO.}

\author{
Caroline Vasconcelos Ribeiro(1)
}

Resumo: O presente trabalho pretende trazer à tona a meditação heideggeriana em torno da mudança da concepção de verdade operada ao longo da História da Filosofia desde a alétheia pré-socrática à veritas moderna. Visa apontar que os fundamentos ontológicos da verdade que herdamos do pensamento moderno ainda norteiam nossa compreensão do real marcada pela calculabilidade, pela impostura da busca de certeza, do auto-asseguramento racional. Visto que nesta forma de pensar não há "lugar" para o que não é passível de ser determinado, manipulado e controlado, buscamos acentuar que a passagem de alétheia para veritas não se trata de uma simples mudança conceitual, mas de uma mudança radical nos modos de ater-se a tudo que é, ao ser. Por fim, pretendemos, à luz do pensamento heideggeriano, indicar que a Educação, na medida em que é subserviente à ditadura do êxito e das competências, torna-se debitária deste modo de pensar moderno e da concepção de verdade que lhe subjaz.

O filósofo alemão Martin Heidegger (1889-1976), considerado um dos maiores pensadores do s éculo XX empreende um projeto filosófico marcado pela investigação ontológica de temas recorrentes na história da filosofia, tais como: verdade, realidade, mundo, conhecimento, enfim. Contudo, este filósofo nos alerta que toda investigação filosófica que pretenda problematizar estes temas deve esbarrar-se necessariamente na tarefa de investigar o ser, o sentido do ser. Sendo assim, para Heidegger, o ser enquanto questão é o tema filosófico por excelência, "responsável" pelo próprio nascimento da filosofia enquanto tal.

Ora, se estamos aqui falando da própria origem (arché) da filosofia e da questão do ser como sua questão inaugural e fundamental, convém, mesmo que brevemente, indicar o modo como Heidegger entende o nascimento da filosofia entre os antigos, isto é, como se dá a "convocação" para o pensamento fazer-se filosofia. Visto que desde a perspectiva heideggeriana não poderemos pensar os fundamentos ontológicos da verdade nos furtando da tarefa de investigar os modos como a tradição filosófica ateve-se ao ser, devemos então, para levar a cabo a empresa deste artigo, meditar sobre a própria origem da filosofia, uma vez que a questão do ser é sua questão inaugural. 
Para aproximarmo-nos do que seja filosofia em seu nascimento e concretização enquanto tal, apoiaremo-nos no texto Que é Isto - a Filosofia? (1950), no qual Heidegger propõe um caminho.Tal caminho consiste em indicar a proveniência grega não só da palavra filosofia, como também do modo como elaboramos tal questão. Sendo assim, nos alerta para o fato de que a pergunta "que é isto" ( $t i$ estín.) é uma forma de questionar desenvolvida por Sócrates, Platão e Aristóteles $e$, "aquilo que o 'que' significa se designa como quid es, tó quid: a quidditas, a qüididade" (1991a, p. 15). Isto quer dizer: a pergunta "que é isto?", pergunta pela qüididade de uma coisa, pergunta por aquilo que constitui sua natureza mais própria, pergunta por sua essência(2).

Platão e Aristóteles nos indicam que a filosofia nasce do espanto (thaumázein) diante do real, diante do fato de as coisas serem o que são e como são. Assim, é pelo espanto que os homens chegam à origem do filosofar(3). Mas, o que no real tem a força de causar tal espanto?

O que, consoante a Heidegger, lança os gregos no espanto é o fato de que, não obstante a multiplicidade das coisas que compóem o real e as diferentes formas de compreendê-las, todas as coisas têm em comum o fato de serem, pois tudo se recolhe no ser. No entanto, apesar do ser estar presente em todas as coisas, em tudo que se diz e compreende sobre as coisas, não se esgota em nenhuma delas, não se deixa encontrar determinado em nada. Deste modo, é plenitude de possibilidade (ibid., p. 17). O ser surge como presença inaudita e espantosa. Assim, "singela e desafiadoramente, o grego, no abrir-se e inaugurar-se de nossa tradição, de nosso destino, perguntou: ti tò ón - que é o real, o real enquanto real, a realidade do real?"(Fogel, 1996, p. 6).

O que, na verdade, seqüestra o grego de sua relação cotidiana com o real é a percepção de que, não obstante todo ente seja no ser, o ser, por sua vez, não se encontra determinado "nem no ente ou dentro do ente nem simplesmente em qualquer outro lugar"(Heidegger, 1978, p. 60). Deste modo, a filosofia nasce da estranheza do grego diante do que sempre se recua, se subtrai. Diante do que, apesar de estar em todos os entes, não se deixa apreender em ente algum. "Ente no ser: isto se tornou para os gregos o mais espantoso" "(Heidegger, 1991a, p. 17).

Na medida em que nos possibilitamos uma compreensão do que seja o espanto originador da filosofia, sentimo-nos no direito de perguntar: em linhas gerais, como se deu, ao longo da história da filosofia, a disposição dos pensadores diante dos enigmas suscitados pelo real? Em outros termos: como se desenvolveu a filosofia em sua inquietude diante do ser do ente?

Antes de tentarmos responder tais questões, convém relembrar o intuito último de nosso texto. Interessa-nos primordialmente apontar para a concepção filosófica de verdade que subjaz como base epistemológica para teorias em Educação e repercute na caracterização do fracasso escolar. Para tanto, torna-se imperativo indicar a mudança da concepção pré-socrática de verdade (alethéia) para a verdade modernamente concebida como adequação (conexum rerun). Visto que o pensamento heideggeriano é guia de nossas inquietações, o meditar acerca do 
inaugurar da filosofia e dos modos como esta tradição pensou o ser impõe-se como tarefa preliminar a todo este empreendimento.

Voltemos à questão acima. Posto que as manifestações do ser do ente apontam para a caracterização do ser como pura possibilidade, pura indeterminação, perguntamos como se opera o testemunho dos filósofos diante deste enigma.

Guiados por estas questões, somos obrigados neste momento a delimitar a forma de lidar com o legado do pensamento que optamos por adotar. Convém deixar claro que não pretendemos realizar uma explicitação sistemática da maneira como os principais pensadores ocidentais se portaram diante do que, na realidade, os espantou. Visamos apenas perguntar, guiados por Heidegger, o que essencialmente caracterizou a forma de a filosofia suportar a convocação da manifestação do ser do ente, isto é, como se deu, em breves considerações, o perscrutar da multiplicidade das vozes do ser.(4)

Diante da impossibilidade de se concretizar, de modo determinado, um discurso sobre o ser, resta ao filósofo grego perguntar se não haveria algo que subsistisse e persistisse enquanto essência necessária a tudo que é. Isto é, resta-lhe procurar um princípio de inteligibilidade capaz de determinar que em tudo aquilo que é e se apresenta, há algo que essencialmente faz com que isto seja. Assim, o pensamento é conduzido para o âmbito do que é passível de se determinar, para o âmbito dos entes. O ente no ser é o que é propriamente procurado. Uma tal procura se articula a uma questão: que é o ente, enquanto é? Para Heidegger esta pergunta é essencialmente metafísica. Nasce da busca de determinação do que no real persiste apesar de toda multiplicidade e indeterminação do ser. Assim, a filosofia visa a interpelação do ente a partir daquilo que dele se mostra enquanto tal. Entretanto, ao determinar o âmbito dos entes como esfera das articulações de seu pensamento, a filosofia abandona o âmbito da pura possibilidade, abandona ao eleger como alvo no real o que é passível de determinações. Ela o faz calcada na evidência da indeterminação do ser, priorizando o ente naquilo que dele se pode apontar e determinar como o que lhe é essencial e necessário. Neste sentido, para Heidegger, filosofia é o mesmo que metafísica e nasce com Platão e Aristóteles, na medida em que visam a construção de um saber calcado no que é determinável no real (1991a, p. 60-63).

Na medida em que se pergunta pelo que o ente é (ti tò ón) a filosofia não pergunta por este ou aquele ente em particular, mas pelo que persiste e está a base de tudo o que é, pelo ente em sua totalidade, em sua entidade. A procura pela entidade do ente, é a procura do que se apresenta disponível e passível de ser determinado. $\mathrm{O}$ ser do ente consiste na entidade. Por conseguinte, a filosofia, enquanto metafísica, volta-se para o ser, não tomando-o como pura possibilidade indeterminada mas, como o que está na base de tudo o que é, ou seja, do ente. Visando o ser como o que se determina nos entes, o pensamento dirige-se para um âmbito de investigação que desconhece, ou se quisermos, descarta as limitações impostas por sua indeterminabilidade, voltando-se para o que se manifesta constantemente, para a presença do que se presenta. 
Circunscreve-se assim, um solo a partir do qual se suportará as convocações do ser do ente; porém, neste esforço de pensá-lo, almeja-se apenas o que se apresenta como substrato de tudo o que é. A pergunta ti tò ón é a forma de interrogação cujos termos são a semente e articulação dinâmica desta forma grega de pensar.

É preciso apontar que Heidegger afirma que é no "momento" em que o âmbito do que se deve pensar é circunscrito pela busca da entidade do ente, que nasce a filosofia. Antes desta delimitação do arco do pensamento, o que caracterizaria a experiência pré-socrática, não existia ainda a philosophía. A palavra philósophos presumivelmente criada por Heráclito, significava "aquele que ama o sophón" (hós philein tò sophón). Sendo que neste contexto, philein, "amar", tem a acepção heraclitiana de homolegein: falar assim como o lógos fala, estar de acordo (harmonia) com o que se revela. E sophón significa: todo ente é no ser, o "é" designa algo assim como "recolher". O ser é experienciado como recolhimento numa correspondência ao lógos. Na medida em que surgiram os ataques do entendimento sofista, que tinham em mãos explicações para tudo e as difundiam, mesmo os gregos tiveram que salvaguardar o poder de espanto do mais espantoso (1991a, p. 16). Assim, tal salvaguarda se deu na medida em que alguns fizeram um caminho não como simples correspondência ao sophón, mas como um aspirar por ele:

Uma tal procura que aspira pelo sophón, pelo hèn pánta, pelo ente no ser, se articula agora numa questão: que é o ente, enquanto é? Somente agora o pensamento torna-se 'filosofia'. Heráclito e Parmênides ainda não eram 'filósofos'. Por que não? Porque eram os maiores pensadores. Maiores não designa aqui cálculo de rendimento, porém aponta para outra dimensão do pensamento. Heráclito e Parmênides eram 'maiores', no sentido de que ainda se situavam no acordo com o logos, quer dizer, com o hèn pánta. O passo para a 'filosofia', preparado pela sofística, só foi realizado por Sócrates e Platão. Aristóteles então, quase dois séculos depois de Heráclito, caracterizou este passo com a seguinte afirmação: Kaì dè kaì tò pálai te kaì nyn kaì aeì zetoúmenon kaì aeì aporoúmenon, ti tò on? (Metafísica, VI, 1, 1028b2 ss). Na tradução isso soa: 'Assim, pois, é aquilo para o qual (a filosofia) está em marcha já desde os primódios, e também agora e para sempre e para o qual sempre de novo não encontra acesso (e que é por isso questionado): que é o ente? (ti tò on) (Heidegger, 1991a, p. 17).

A partir da citação acima podemos observar que Heidegger demarca uma radical diferença entre o pensamento pré-socrático e a filosofia grega, tal como esta se origina, a saber, pela veiculação da pergunta pelo ente enquanto o que subsiste em meio à indeterminação do ser. Sendo assim: "A caracterização aristotélica da filosofia não se deixa absolutamente retraduzir no pensamento de Heráclito e Parmênides"(ibid., p. 19).

Se a filosofia enquanto metafísica circunscreve como âmbito legítimo de investigação o que permanece imutável e necessário, o pensamento pré-socrático, por sua vez, experiencia o ser em "obediência" ao que se mostra tal como se mostra, isto é, em harmonia com a dinâmica de indeterminação do ser, sem a 
pretensão de torná-lo claro, logicamente inteligível, buscando uma aproximação desta experiência no que ela engendra de velado, obscuro.

O adjetivo "obscuro" nos remete, de chofre, à figura de um pensador pré-socrático, a saber, Heráclito. Esta opinião amplamente disseminada a seu respeito, tem sua proveniência em colocações do escritor romano, Cícero, para o qual o pensador de Éfeso escreveu intencionalmente de modo obscuro.(5) Discordando, não da obscuridade atribuída por Cícero a Heráclito mas, da delegação da mesma a um ato intencional do entendimento, Heidegger reivindica o estatuto de obscuro a Heráclito, não porque este se exprime de forma (proposital ou não) incompreensível mas, porque a obscuridade provém da própria essência do que se pensa. Em outros termos: Heráclito é obscuro porque pensa o ser enquanto "algo" que furta, deste modo, seu pensamento pronuncia-se numa correspondência com o que assim se pensa. Sua palavra abriga o "obscuro", não no sentido comum de algo mergulhado nas trevas mas, numa intimidade com o mistério do que se mostra.

Vimos acima que Heidegger não denomina Heráclito e Parmênides de filósofos mas de "maiores pensadores", em outras passagens ele é mais incisivo e denominaos de pensadores incipientes (anfängliche Denker).(6) Uma vez demarcada esta diferença, cabe-nos perguntar como os pré-socráticos pensaram o ser, mais especificamente e atendendo à demanda primordial de nosso texto, como os présocráticos pensaram ao ser em sua verdade?

Vale pontuar que não faz parte do escopo deste trabalho uma análise sistemática de fragmentos destes pensadores à luz do método de apropriação hermenêutica de Heidegger, muito menos polemizar com os etimólogos e filólogos da língua grega as peculiares interpretações heideggerianas. Visamos apenas, fazer referência à experiência pré-socrática de ser, demarcando que a mesma é marcada pela dinâmica da alethéia. Estamos então, no direito de reiterar a pergunta: como se constitui esta dinâmica da verdade do ser (alethéia) na alvorada do pensar grego?

Visto que Heidegger nomeia Heráclito e Parmênides como os "maiores" pensadores, marcando a harmonia destes com a verdade do ser, nos ateremos a Heráclito como representante deste modo de pensar, entendendo que sua perspectiva de "obediência" ao modo como o ser se dá, para Heidegger, é a mesma de Parmênides e Anaximandro. Salvo, claro, os diferentes modos de dizêlo.

Ao interpretar o fragmento 16: "Como alguém poderia manter-se encoberto face ao que nunca se deita." e o 123: "O surgimento (Physis) favorece o encobrimento", Heidegger aponta a experiência heraclítica de ser como Physis, entendida como o vigor dominante daquilo que brota e permanece (nunca se deita), não obstante favoreça o encobrimento. Assim "Physis é o surgir (Ent-stehen), o extrair-se a si mesmo do escondido e assim conservar-se."(7)

Com o intuito de compreendermos melhor a dinâmica da physis, do surgir a partir de si mesmo, poderíamos recorrer apressadamente a analogias com a própria 
dinâmica da natureza, tomando como exemplo o surgir da semente escondida na terra, o nascer do sol, enfim, poderíamos recorrer a todos os chamados "processos naturais". Esta é a perspectiva que guia a tradução latina de physis por natura, que propriamente significa nascer, nascimento. Contudo, esta tradução distorce a força evocativa desta palavra pois, se physis pode ser experimentada nos processos naturais, não se identifica ou se restringe, entretanto, a estes fenômenos. Portanto:

Os gregos não experimentaram o que seja physis nos fenômenos naturais. Muito pelo contrário: por força de uma experiência fundamental do Ser, facultada pela poesia e pelo pensamento, se lhes desvelou o que haviam de chamar physis. Somente em razão deste desvelamento puderam ter olhos para a natureza em sentido estrito (Heidegger, 1978 , p. 45).

A apropriação desta experiência do ser como 'o surgir que se mantém em si mesmo consistente', caminha no sentido de priorizar a consistência ("nunca declina"), eliminando a referência ao encobrimento, esquecendo-se de que no "nunca declinar" está implicado o encobrimento. Assim, atribui-se ao ser uma vigência permanente, ousia. Desde esta ótica, a physis é entendida como a "natureza" das coisas, como a essência que subsiste em tudo o que é. Esta forma de compreensão de physis=natureza =essentia=ousia aparece no pensamento grego com Platão, tornando-se normativa para posteriores concepções de ser. Contudo, esta forma de pensar não está em correspondência com Heráclito na medida em que este pensador expõe um nexo essencial entre o surgimento e o declínio, isto é, na medida em que não há em seu pensamento a primazia do que subsiste sobre o encobrimento, o declinar. Tal nexo é apontado de maneira decisiva no fragmento 123: "O surgimento favorece o encobrimento".(physis kriptesthay philei).

Segundo Heidegger (ibid., p.139-146), o favor (philia/philei) deve ser entendido como uma propiciação originária que convém à essência do outro. É enquanto favorecimento que a relação essencial entre physis e kryptesthai se constitui, isto é, só podemos pensar o surgimento a partir de sua unidade favorecida com o encobrimento. Em outras palavras: o surgir não vigoraria se não estivesse, primeira e necessariamente, resguardado no encobrimento.

Retomando a questão suscitada acima, temos que o ser em Heráclito se destina como physis. Neste destinar encerra o jogo de se desvelar, de vir à luz como emergência, numa unidade indissociável com o ocultamento; e é porque surge do ocultamento que se inclina para ele, como "aquilo" que garante o seu surto. Este jogo travado entre "contrários" é o embate (pólemos) que engendra tudo o que é, tudo o que vigora e se mantém no vigor.(8) Pólemos é o embate que a eclosão deve travar para emergir, apesar do retiro de onde provém e que a espreita. A grande época desta experiência grega de ser "foi a única auto-afirmação criadora da turbulência no jogo de tensão"(ibid., p. 133) entre emergência e ocultação. Época marcada pela afirmação do pólemos constitutivo do destinar-se do ser. Neste sentido, o ser enquanto plenitude de possibilidade, ao vir à luz como emergência, esconde o traço decisivo de sua essência, a fonte oculta de onde procede o desvelamento. Por isso, respondendo inquietações levantadas ao longo 
deste texto, podemos dizer que a experiência de ser na alvorada do pensamento é a experiência do seu destinar-se enquanto retiro.

Trazendo a compreensão dessa dinâmica para a relação entre ser e ente, temos que ser é a eclosão, o irromper que garante que o ente surja e se mantenha enquanto presença. O ser, marcado constitutivamente pelo pólemos "(...)é a presença predominante ainda não dominada pelo pensamento. Nesse vigor (Walten) o presente se apresenta como ente. A vigência de tal vigor só se instaura a partir do ocultamento. Isso significa para os gregos: alétheia (desocultamento) se processa e acontece, quando o vigor se conquista a si mesmo (...)" (Heidegger, 1978, p. 89).

A experiência do ser como vigor, como presença que surge da ocultação, é marcadamente a experiência da alvorada do pensamento, isto é, a experiência de pensamento dos pré-socráticos. O ser é experienciado desde a dinâmica da desocultação que se instala a partir do velamento, desde a alétheia. Este modo de ater-se ao ser é marcado por um deixar-ser o que se mostra, não há pretensão de dominar o vigor pelo pensamento.

Segundo Heidegger, ainda no âmbito do pensar grego, opera-se um desvio desta experiência inicial, desvio este, inaugurado por Platão, na medida em que visa no ser o que é consistente, o que nele permanece passível de determinação.

Para Platão, a busca pelo que consiste e persiste no real está articulada ao que no ente se expõe e se oferece ao encontro de uma visão. Ora, tudo que é e está presente, possui um aspecto (Aussehen). No aspecto (eidos) o ente se faz presente, ou seja, o aspecto é o modo como o ser mantém o ente presente naquilo que ele é. Compreende-se então o ser como algo passível de ser determinado, pois, persiste em tudo o que é, deste modo, deixa-se de pensá-lo em sua dimensão indeterminabilidade. Assim, "para Platão, o reino estável do ser é o objeto do próprio conhecimento" (Kahn, 1997, p. 24).

Na medida em que reside na Idea a determinação qüididativa de "tudo que é", o ser, converte-se no ente propriamente (ontos on), e o ente, a coisa em constante movimento de geração e degradação, Platão o chama de me on. Este ente, por sua vez:

(...) desfigura sempre a idéia, o puro aspecto, ao realizá-la, configurando-a na matéria. Por seu turno, a idéia se torna o paradeigma, o paradigma, a figura exemplar. Assim a idéia se converte necessariamente em ideal. $\mathrm{O}$ exemplo, que se configura segundo a figura exemplar, não "é", em sentido próprio, mas tem apenas parte no Ser, méthexis. Rasga-se e se estabelece o chorismós, o abismo entre a idéia, como ente propriamente, a figura exemplar e originária, e o não-ente propriamente, o exemplo configurado e imitado (Heidegger, 1978, p. 204).

A Idea entendida como o ser do ente, é o que é propriamente a sua essência, seu puro aspecto, perfeito e imutável, e o ente, em sua materialidade, nada mais é do que cópia imperfeita do puro aspecto. Assim, o que aparece, o ente, surge como 
cópia do exemplo, o que implica dizer que o aparecer, a aparência, passa a ter a conotação de defeito, ilusão. Na medida em que a Idea é o modelo exemplar, todo presentar-se dos entes deve se igualar, se conformar ao modelo. A verdade do ser enquanto jogo de retraimento e manifestação (alétheia), converte-se em correção da visão, Orthotes, em adequação, Homóisis.(9)

A physis se converte em Idea (paredeigma), a verdade em correção. O lógos se faz enunciado, o lugar da verdade enquanto correção, a origem das categorias, o princípio fundamental das possibilidades de ser. "Idea" e "categoria" serão no futuro os dois títulos que a que se submenterá o pensar, o fazer e o julgar, toda a existência do Ocidente (ibid., p. 208).

O enunciado, o lógos, torna-se o sítio da verdade enquanto adequação (Homóisis), só sendo possível atingir o verdadeiro quando o enunciado se regula pelo modelo exemplar. Aquilo que em toda interpelação está sempre presente como substrato (Hypokeimenon) para todo enunciar, é o ser mesmo.(10) Como se deveria então, abordar o ser e expressá-lo num enunciado? Ora, deve-se indicar, apontar-lhe na "cara" o que nele subsiste e é passível de determinação, isto significa categorizar. Categoria torna-se o ser que se enuncia em cada lógos, seu traço fundamental.(11)

Ora, apesar de Aristóteles instituir o categorizar como o modo primordial de predicar o ser, de dizer o que uma coisa é, sabemos que nossa tradição filosófica é herdeira desta postura diante do real, sendo assim, reverberamos, milênios depois, este modo de determinar o que uma coisa é, enclausurando-a em categorias. Ora, nós educadores convivemos com teorias que não fazem nada mais do que enclausurar os educandos, suas conquistas e suas "fraturas" em categorias, colocando-as em gráficos, determinando padrões. Sejam estas teorias guiadas por modelos organicistas ou mentalistas sabemos que elas ainda norteiam muitos pesquisadores e educadores, quando estes investigam as causas do fracasso escolar.(12) Este modo de apreender a realidade educacional é também herdeiro de uma concepção de verdade que visa correção segundo um modelo exemplar, aliás, correção de textos, de provas, de ditados etc. Lembremos o quanto muitos educadores estabelecem um modelo ideal de aluno, de respostas, de raciocínio que, como a Idea platônica, impõe-se como paradeigma a ser alcançado, de modo que aqueles que não logram êxito em se aproximarem do Ideal, são vistos como fracassados, diferentes, ou até mesmo, deficientes. Mas, deixemos para mais tarde esta relação entre concepção de verdade e o "olhar" sobre o fracasso escolar, antes, cuidemos de precisar melhor este pensamento filosófico, do qual, mesmo sem atentarmos para este fato, somos herdeiros.

Falamos da alétheia como a experiência pré-socrática de verdade que, segundo Heidegger, contrapõe-se a este modelo normativo acima descrito. Mas, convém, precisar melhor esta experiência destes primeiros pensadores.

Visando alcançar o sentido desta palavra a-lethéia na alvorada do pensamento grego, Heidegger aponta que esta não só significa desvelamento, mas, decisivamente, diz a saída da lethé (ocultação), o surto ao aparecer, indicando assim, que o termo a-létheia se caracteriza por um a- que não deve ser entendido 
estritamente como um "privativo". Expliquemos melhor: o a- ("não") aponta para o traço essencial do que está desvelado, isto é, para o fato de que este só "é" surgindo de uma (lethé). Assim, o que é desvelado (o ente) só se pode desvelar em função de uma outra dimensão que se mantém oculta, que não se desvela. Tal dimensão não pertence ao ente, mas, constitui o ser. Quer dizer: o que se dá constantemente como presente pressupõe necessariamente o que se furta, se subtrai. Torna-se inconcebível pensar o desvelamento fora da sua relação constitutiva com a ocultação, de modo que " (...) lethé, faz parte da alétheia, não como por acréscimo, não como a sombra faz parte da luz, mas como coração da alétheia" (Heidegger, 1991a, p. 80).

Quando se é guiado por uma concepção da verdade como correção, a dinâmica de desvelamento-ocultação não é "percebida" em proveito do que permanece desvelado: a entidade do ente. Ao passo em que o pensamento toma como sua tarefa a apreensão do real segundo o crivo da consistência e subsistência, opera-se a conversão de alétheia em orthotes.

Heidegger nos indica que é sobre este solo "firme" que se ergue a História do pensamento metafísico. O que representa ameaças a esta rigidez conceitual é desconsiderado como digno de ser pensado, isto é, é dis-pensado como supérfluo.(13) Caracteriza-se assim, o ocaso do pensamento do ser em sua verdade (alétheia), instaura-se o seu esquecimento. Para Heidegger, o cume do esquecimento de que na dinâmica do ser permanece sempre algo de enigmático, de oculto, ou seja, a radicalização do esquecimento será operada pelo pensamento moderno inaugurado por Descartes.

Heidegger (1991a) salienta que Descartes, em suas Meditaçóes, não pergunta apenas e em primeiro lugar "O que é o ente, enquanto é?" mas, prioritariamente, pergunta pelo ente no sentido do ens certum, do ente verdadeiro. Tal pergunta é veiculada pela dúvida que, por sua vez, torna-se instrumento metódico para se chegar ao conhecimento verdadeiro. Ao descobrir que pode duvidar de tudo que considera conhecimento, reconhece a dúvida como um ato de pensamento que lhe garante, indubitavelmente, a certeza de pensar. Mais que isto, a certeza de sua existência. Descartes então intui: "Penso, logo existo". Eis a descoberta que afirma a existência do sujeito intimamente dependente de seu ato de pensar. O sujeito se percebe consciente de ser sujeito dos seus atos de consciência. O pensamento é, então, o modo como o sujeito re-apresenta para si aquilo que se lhe opõe, que dele se distingue, isto é, a realidade em sua dinâmica. O cogito é a força de representação, de re-apresentar tudo o que se mostra e se apresenta lançado diante do sujeito. Isto que se apresenta e se opõe ao sujeito é, por sua vez, denominado objeto. Perguntar pelo que é o ente significa aqui, conhecê-lo, representá-lo enquanto objeto de uma representação. O sujeito (a consciência) é visto, portanto, como o fundamento de compreensão da realidade, transformando a certeza no critério de verdade, quer dizer, na medida do real (Fogel, 1986, p. 47). Assim, através da emissão de juízos verdadeiros, o sujeito irá determinar o que são as coisas, isto é, os entes, atendo-se a estes, enquanto objetos, com o intuito de manipulá-los e dominá-los.(14) Enquanto consciência, enquanto ato de 
pensamento, o sujeito re-apresenta o ente a partir de algo que é prévio, a partir de sua própria subjetividade:

Assim, o ego se transforma no sub-ectum por excelência, e, desta maneira, a essência do homem penetra pela primeira vez na esfera da subjetividade no sentido da egoidade. Do acordo com esta certitudo recebe o dizer de Descartes a determinação de um clare et distincte percipere. A disposição afetiva da dúvida é o positivo acordo com a certeza. Daí em diante a certeza se torna a medida determinante da verdade. A disposição afetiva da confiança na absoluta certeza do conhecimento a cada momento acessível permanece o páthose com isso a arché da filosofia moderna (Heidegger, 1991a, p. 22).

Visto que tal filosofia está fundamentada na certeza advinda do cogito, isto é, que seu próprio fazer-se enquanto tal constitui-se como ação do sujeito do conhecimento, Heidegger a denomina de metafísica da subjetividade. Nesta forma de pensar não há lugar para o que não é passível de ser determinado, manipulado e controlado. A impostura da busca de certeza, do auto-asseguramento, faz com que o pensamento leve a cabo a construção de métodos que garantam a via correta de acesso aos objetos. A realidade é vista como algo que deve ser mapeado e planificado através de procedimentos seguros de conhecimento. Ora, salta-nos aos olhos que nesta esfera de pensamento não há lugar possível para se pensar a verdade do ser como alétheia, isto é, não cabe pensá-la em toda a sua dinâmica de doação e subtração, afinal, para que um pensamento garanta uma segura fundamentação, deve eliminar do seu campo o que é em si mesmo inapreensível.

Reconhecendo-se a indeterminação do ser e conduzindo o pensamento para o solo firme do domínio dos entes, a metafísica instala-se como um tipo de dominação que seqüestra o que é enigmático (e por isso mesmo limita as possibilidades de certeza), visando, num terreno preciso, construir um saber que desconhece restrições.(15)

Como vimos, ao longo da história da filosofia, prevaleceu esta forma de proceder em relação à realidade. $\mathrm{Na}$ investigação da entidade do ente, isto é, do ente em seu ser, o ser é pensado como o substrato, o fundamento de tudo o que é, assim, para Platão o que subsiste é o aspecto (eidos), para Aristóteles a substância (categoriazável) e para Descartes, a certeza que se apresenta como inabalável: $O$ cogito ergo sum. Não obstante as peculiaridades das produções de cada filósofo, o que permanece como traço comum é a investigação do ser como fundamento substancial, imutável e estático dos entes, o que significa dizer que a metafísica furta-se da tarefa de pensá-lo em seu caráter de pura possibilidade, pois, elege como legítimo de se pensar apenas o que é determinável.

A metafísica da subjetividade representa o cume desta forma de pensar que preza pelo determinável e controlável, afinal, compreende todo o real desde a relação sujeito/objeto, relação na qual o sujeito tem por tarefa manipular os entes na busca de certezas comprováveis (conexio rerum). Não é à toa que a Época Moderna, fecundada pelo pensamento cartesiano, torna-se a época em que as ciências 
predominam, fundamentadas em seus procedimentos metodológicos, levando a cabo o conhecimento como instrumento de dominação.

Resumindo: a verdade - seja a Orthotes platônica, a adaequatio rei et intellectus da Escolástica ou a moderna Veritas (conexio rerum) - passa estar sitiada no juízo predicativo, ou melhor, num juízo que exprime a concordância entre o que se enuncia e o objeto apreendido. Sendo assim:

Tanto a interpretação medieval quanto a moderna - que vige de Descartes a Hegel - fundam-se num mesmo pressuposto. Embora emprestando diferentes significados a 'intellectus', como realizador do conhecimento, e a coisa, como objeto de conhecimento laçam mão do mesmo princípio: a conformidade (Nunes, 1992, p. 208).

Esta concepção corrente de verdade não suporta o enigma, o que se oculta. Sua função é estabelecer uma conexão adequada entre o enunciado e a coisa enunciada, de modo que "esta coisa" seja desnudada totalmente pelo sujeito pensante (intellectus) e que esta expropriação do seu mistério seja instituída como normativa e hegemônica. Surgindo, assim, as verdades científicas, inquestionáveis. Esta verdade pretende tudo desnudar, planificar, manipular. Eis a concepção de verdade da qual somos herdeiros, desde a qual fazemos ciência. Desde a qual, infelizmente, muitas vezes nos postamos vorazmente diante de uma realidade educacional criando conceitos e categorias, enquadrando sujeitos, sem maiores questionamentos. Sem considerar a íntima relação entre determinada práxis pedagógica e o conceito de verdade que, silenciosamente, a sustenta.

Essa verdade assim definida apela para e define ao mesmo tempo o seu oposto: a não-verdade. Uma vez que a essência da verdade consiste na concordância, a nãoverdade será não-concordância; e uma vez que a verdade tem seu lugar eminente no conhecimento, a não-verdade será desconhecimento, quer dizer, ainda conhecimento mas conhecimento falseado - erro (Zarader, 1998, p. 65).

Na medida em que reverberamos uma concepção de verdade que pretende tudo desnudar, aniquilar enigmas, estabelecer paradeigmas de adequação do enunciado com a coisa enunciada, herdamos também a concepção de erro que ela sustenta. Ora, "concordância", "conhecimento", "erro" não são termos corriqueiros do cotidiano educacional? Sabemos que as teorias tradicionais em educação, visando a aquisição do status de ciência, foram (são?) subservientes às classificações, categorizações e enquadramentos, oferecidos ora pela medicina, ora pela psicologia da educação, ora pela sociologia, enfim.(16) Mas, o que queremos destacar neste texto, é o fato de que, uma vez que uma ciência está a serviço da categorização e da calculabilidade a ela subjaz um modo de entender o real como algo a ser planificado e manipulado por uma imperiosa racionalidade. Sendo assim, podemos dizer que tanto as teorias tradicionais em educação quanto as ciências que lhe servem de base epistemológica, são debitárias desta concepção de verdade como adequação. 
Testemunhamos ao longo da História da Educação correntes de pensamento que sempre objetificaram o sujeito da aprendizagem, tentando engessá-lo em modelos ideais de rendimento, tendo como referência este modelo de homem racional, centrado em si mesmo e com capacidades para manipular e controlar a dinâmica da realidade.

Ora, o que não cumpre as exigências do avanço ad infinitum, o que obstaculariza o sucesso, acaba sendo visto como fracasso. O que não é útil no cumprimento da metas de êxito, passa a ser visto como algo que deva ser consertado, manipulado até entrar no eixo. Esta ditadura do êxito está presente nas mais variadas esferas da vida: na linha de montagem da fábrica, na família, nos grupos e, é claro, nas escolas. Desde esta perspectiva:

(...) na fábrica e na escola, o que se busca é eficiência máxima, otimização do tempo e dos recursos despendidos. Feito isto, o produto fabricado não é posto no mercado antes de passar pelo controle de qualidade, procedimento que consiste em confrontar todos os itens da mercadoria pronta com as especificações iniciais. $\mathrm{Na}$ escola o procedimento correspondente a esta etapa é a avaliação (Cunha, 2000, p. 64).

A avaliação seria o instrumental que detectaria o disfuncional, o que não se molda, isto é, detectaria o fracasso escolar. Contudo, como lembra Anny Cordié (1996), fracasso é um julgamento de valor, é algo que se opõe ao sucesso. A partir desta ótica "ser bem sucedido na escola é ter a perspectiva de ter, mais tarde, uma bela situação, de ter acesso, portanto, ao consumo de bens. Significa também 'ser alguém', isto é, possuir um falo imaginário, ser respeitado".

Mas, vale perguntar: o que tradicionalmente é visto como sucesso e como fracasso na educação?

Ora, o sucesso é visto como um resultado positivo de uma aprendizagem e o fracasso, como o negativo, o erro. Há várias teorias e perspectivas que versam sobre as conquistas e os fracassos no aprender, entretanto, como a envergadura de nosso texto exige, elegeremos uma concepção de aprendizagem que serve de base epistemológica para teorias tradicionais em educação que, por mais que julguemos aniquilada, se faz presente no cotidiano educacional. Trata-se do Behaviorismo (comportamentalismo).

Segundo Lajonquière (1998), à pedagogia tradicional subjaz um modelo empirista ou comportamentalista de aprendizagem, concebida como uma associação exitosa entre estímulo e resposta. Quer dizer: o erro (ou problema de aprendizagem) é visto como uma associação não-exitosa entre o Estímulo e a Resposta, que deve ser revertida com uma nova programação de estímulos e pode ser evitada com a aplicação de exercícios de fixação. Afinal de contas, o professor tem sempre em mãos um caderno de respostas com as verdades estipuladas, adequadamente estabelecidas e, claro, quem não se adequar será rotulado como diferente, deficiente ou fracassado. E ao pedagogo restaria a função de conhecer as leis da aprendizagem para poder calcular os efeitos dos métodos educativos que coloca 
em ação, tendo em mira uma ortopedia educativa, ou seja, uma adaptação do indivíduo ao "gesso" do conteúdo.(17)

Ao empregar esquemas de reforçamento e punição na modelagem de comportamentos, o behaviorismo forneceu à educação meios de fazer com que o aluno emita condutas desejáveis, adquira os conteúdos escolares sem crítica, de modo que torne-se um indivíduo adaptado e com um histórico escolar repleto de boas notas (Ribeiro, 2003, p. 36).

Esta "filosofia" educativa que consagra a estocagem do conteúdo como fator de soberania e faz apologia à eficiência, faz-se presente em grande parte de nossos espaços escolares. Quando uma práxis educativa está calcada na condução do aprender como armazenagem acrítica de conteúdos, está reverberando, mesmo sem atentar para isto, uma concepção normativa de verdade, um pensamento que estabelece padrões de respostas e comportamentos. Ora, vimos que esta perspectiva é herdada de um pensamento que representa o cume do esquecimento da verdade como jogo que traz consigo tanto o que se desvela quanto o que se mantém enigmático, a saber, a alétheia.

Eis que a seguinte pergunta se impõe: mas, como seria se levássemos em consideração a perspectiva da alétheia para pensarmos o errar e o aprender? Podemos entrever esta resposta lembrando que a marca da alétheia não é o simples desvelamento, a total nudez que estipula uma verdade, mas o jogo de velamento-desvelamento. Neste jogo sempre há algo que se oculta, se mantém enigmático, pois o que se furta é mola propulsora para um novo desvelar. Se não há uma nudez total do real, a verdade mais originária está não no que ora se impõe como tal, mas, está na dinâmica do jogo. Não é esta ou aquela adequação mas, o que garante o jogo. O erro, o errar seria então parte constitutiva desta dinâmica, mola que fomenta novos desvelamentos. O erro não seria visto como algo dejetável e sem função, mas poderia ser entendido como elemento visceral da dinâmica. Ao invés de julgar o erro, rotulando-o como uma experiência de fracasso, este poderia ser pensado como um caminho possível para germinação de novas aprendizagens. Uma vez guiado pela dinâmica de alétheia o educador não conceberá o erro como interrupção fracassada de um processo, em última instância, o compreenderá como um convite para abertura de novas e inesgotáveis possibilidades. Por isso Heidegger nos alerta:

A errância em cujo seio o homem se movimenta não é algo semelhante a um abismo ao longo do qual o homem caminha e no qual cai de vez em quando. Pelo contrário, a errância participa da constituição íntima do Dasein à qual o homem historial está abandonado. A errância é o espaço de jogo deste vaivém no qual a ek-sistência insistente se movimenta constantemente, se esquece e se engana sempre novamente (Heidegger, 1991a, p. 132).(18)

A perspectiva que norteia o pensamento guiado pela alétheia não lida com a dicotomia estanque verdade-erro, mas entende a errância como o fluxo, que mantém o jogo. Sendo assim: 
A errância na qual a humanidade historial se deve movimentar para se dizer que sua marcha é errante é uma componente essencial da abertura do Dasein. A errância domina o homem enquanto o leva a se desgarrar. Mas, pelo desgarramento a errância contribui também para fazer nascer esta possibilidade que o homem pode tirar da ek-sistência e que consiste em não deixar se levar pelo desgarramento. O homem não sucumbe ao desgarramento se for capaz de provar a errância enquanto tal e não desconhecer o mistério do Dasein (ibid., p. 133, grifo nosso).

A partir desta afirmação fica claro que não há em Heidegger uma apologia ao erro ou uma festiva guerra contra as verdades científicas. $O$ filósofo questiona a imposição desta verdade como a única possível e a fundante de todo o pensar. $\mathrm{O}$ questionamento da hegemonia desta verdade no âmbito das teorias educacionais foi o que quisemos denunciar neste texto, lembrando, com Heidegger, que só não sucumbiremos ao desgarramento se dermos "espaço" legítimo à errância.

\section{BIBLIOGRAFIA}

ARISTÓTELES, De Anima. Madri: Ed. Aguilar, 1986

BOSSA, N. Fracasso escolar: um olhar psicopedagógico. Porto Alegre: Artes Médicas, 2002.

BIEMEL, W. "Elucidações acerca da conferência de Heidegger - A Origem da Arte e Destinação do Pensamento" in.: O que nos faz pensar - Cadernos do Departamento de Filosofia da PUC-Rio. Rio de Janeiro: 1986, número 10, vol. 2 , Out/96

CUNHA, M.V. Psicologia da Educação. Rio de Janeiro: DP\&A editora, 2000.

CORDIÈ, A. Os atrasos não existem: psicanálise de crianças com fracasso escolar. Porto Alegre: Artes Médicas, 1996

FOGEL, G." Do Fundamento" in: Revista de Filosofia da Universidade Federal da Paraíba - Mestrado em Filosofia. João Pessoa: Ed. Idéia, Novembro/96, n 3.

. "Martin Heidegger, et coetera e a Questão da Técnica " in.: O que nos faz pensar - Cadernos do Departamento de Filosofia da PUC-Rio. Rio de Janeiro: 1986, número 10, vol 2.

HEIDEGGER, M. Introdução à Metafísica. Tradução e notas Emmanuel Carneiro Leão. Rio de Janeiro: Ed. Tempo Brasileiro, 1978.

Nova Cultural, 1991a.

Que é isto - a filosofia? Tradução Ernildo Stein. São Paulo: ed.

Sobre a essência da verdade. Tradução Ernildo Stein. São Paulo:

ed. Nova Cultural, $1991 b$. 
Que é Metafísica? Tradução Ernildo Stein. São Paulo: ed. Nova Cultural, 1991c.

O Fim da Filosofia e a Tarefa do Pensamento, Tradução Ernildo Stein. São Paulo: ed. Nova Cultural, 1991d.

Ser e Tempo. Tradução e notas Márcia Sá Cavalcante. Petrópolis: ed.Vozes, 1995.

Heráclito. Rio de Janeiro: Relume Dumará, 1998.

LAJONQUIÈRE, L. Para Repensar as Aprendizagens de Piaget a Freud: A (psico) Pedagogia Entre o Conhecimento e o Saber. Petrópolis: Vozes, 1998.

LEÃO, E. C. Heráclito, fragmento, origem do pensamento. Rio de Janeiro: Ed. Tempo Brasileiro, 1980.

KAHN, C. O Verbo Grego Ser e o Conceito de ser - Cadernos de Tradução Rio de Janeiro: PUC,1997,

NUNES, B. Passagem para o Poético. São Paulo: Ática, 1992.

RIBEIRO, C.V. "Um breve olhar heideggeriano sobre bases epistemológicas da Psicologia da educação".in: Aprender - Caderno de Filosofia e Psicologia da Educação. Vitória da Conquista: ed. Uesb,2003.ano I, vol I.

ZARADER, M. Heidegger e as Palavras da Origem. Lisboa: Ed. Instituto Piaget. 1998.

Notas

(1) Mestre em Filosofia pela Universidade Federal da Paraíba, Doutoranda em Filosofia da Psicanálise na Unicamp e professora assistente na Universidade Estadual do Sudoeste da Bahia (UESB).

(2) cf.: Aristóteles, De Anima. Madrid: Ed. Aguilar, 1986, p. 141.

(3) Esta referência é feita por Heidegger em Que é isto - a Filosofia?. As passagens de Platão e Aristóteles referentes ao espanto (Thaumazéin) enquanto origem imperante da filosofia encontram-se nos seguintes textos:Platão, Diálogos Teeteto- 155d e Aristóteles, A Metafísica-1, 2,982 b. cf.: Heidegger, M. Que é isto a filosofia? p.15.

(4) Ao fazermos esta delimitação acerca do propósito do nosso texto em relação à história do conceito de ser vigente no legado da tradição filosófica, estamos calcados na perspectiva heideggeriana de entendimento do registro histórico. Para 
Heidegger, perguntar pela forma como a filosofia pensa o ser não implica, necessariamente, um resgate formal dos conceitos passados, como se estes estivessem expostos na "galeria histórica dos conceitos" e fossem algo que não vigorasse mais no âmbito do pensamento contemporâneo. Esta é a perspectiva historiográfica, cuja tarefa se restringe ao levantamento de dados registrados acerca deste conceito. Entretanto, por conceber que as representações do conceito de ser não são da ordem do passado resoluto mas, ao contrário, são representações correntes que guiam nossa forma não só de compreender o ser, como também, nosso próprio fazer filosófico, Heidegger afirma que não se trata então, de fazer "uma computação historiográfica de diferentes concepções" de ser, mas ,de perguntar "como o ser se atém a nós e em que pé nos encontramos hoje com o ser" cf.: Heidegger, M. Heráclito. Rio de Janeiro: Relume Dumará, 1998, p.118.

(5) cf.: Cícero, "De Natura Deorum I, 74". in.: Heidegger, M. Heráclito. p.35

(6) cf.: Biemel, W. "Elucidações acerca da conferência de Heidegger - A Origem da Arte e Destinação do Pensamento" in.: O que nos faz pensar - Cadernos do Departamento de Filosofia da PUC-Rio. Rio de Janeiro: 1986, número 10, vol. 2 , Out/96.

(7) Heidegger, M. Introdução à Metafísica. p. 45. Usamos a seguinte tradução brasileira para os fragmentos: Leão, E. C. Heráclito, fragmento, origem do pensamento. Rio de Janeiro: Ed. Tempo Brasileiro, 1980.

(8) Esta referência é ao fragmento 53 de Heráclito. Faremos uma compilação parcial do mesmo, a partir da tradução de Heidegger: "A disposição (Pólemos) é o que engendra todos (os presentes), como (também), o que conserva, mantendo-se em vigor em todos (...)"Heidegger, M. Introdução à Metafísica. 1978, p.89.

(9) Cf.: Heidegger M. La Doctrine de Platon sur la Verité. Traduit par André Préau, Pari: Gallimard, 1968.

(10) cf: Heidegger, M. Ser e Tempo. Tradução e notas Márcia Sá Cavalcante. Petrópolis: ed.Vozes, 1995. § 7.

(11) Em Ser e Tempo Heidegger nos lembra que a partir de Platão e Aristóteles cabe a filosofia interpelar o real acusando, denunciando a estrutura necessária do ser dos entes. Este modo de interpelação diz-se, para os gregos, do ato de categorizar. O que significa "(...) dizer na cara dos entes o que, como ente, cada um deles é, ou seja, deixar e fazer todos verem os entes em seu ser.". cf. : Heidegger, M. Ser e Tempo, p.81 parte I.

(12) cf.: Lajonquière, L. Para Repensar as Aprendizagens de Piaget a Freud: A (psico) Pedagogia Entre o Conhecimento e o Saber. Petrópolis: Vozes, 1998.

(13) Em Ser e Tempo, ao se referir à metafísica como a história do esquecimento, o filósofo indica que para esta tradição a questão sobre o sentido do ser é tida como supérflua. cf.:Heidegger, M. Ser e Tempo. §1. p. 28. 
(14) Vale trazer aqui uma passagem da sexta parte do Discours de la Méthode pour Bien conduire las Rasion et Chercher la Verité dans les Sciences. Escreve Descartes: "(...) il est possible de parvenir à des connaissances qui soient fort utiles à la vie, et qu'au lieu de cette philosopie spéculative qu'on enseigne dans les écoles, on en peut trouver une practique pour laquelle, conaissant la force et les actions du feu, de l'eau, de l'áir, des astres, des cieux et de tous les autres corps que nous environnent, aussi distictement que nous connaissons les divers métiers de nous arisans, nous les poirrions emploiyer en même façon à tous les usages auxquels ils sont propes, et ainsi nous rendre maîtres et possesseurs de la nature" in: Fogel, G. ibdem, p.45.

(15) "Com o ego cogito de Descartes, diz Hegel, a filosofia pisou pela primeira vez terra firme, onde pode estar em casa".Heidegger, M. O Fim da Filosofia e Tarefa do Pensamento. p75.

(16) cf.: Bossa, N. Fracasso escolar: um olhar psicopedagógico. Porto Alegre: Artes Médicas, 2002.

(17) Trabalhamos anteriormente esta questão em: Ribeiro, C.V. "Um breve olhar heideggeriano sobre bases epistemológicas da Psicologia da Educação".in: Aprender - Caderno de Filosofia e Psicologia da Educação. Vitória da Conquista: ed. UESB, 2003. Ano I, vol I.

(18) Para Heidegger, o homem existe apenas numa relação com o ser, assim, para reunir, ao mesmo tempo, numa palavra, tanto a relação do ser com a essência do homem, como também esta referência fundamental do homem à abertura ("aî") do ser enquanto tal, escolhe a palavra Dasein, que literalmente significa "ser-aí". Por existir uma certa diversidade na tradução deste termo, optamos mantê-lo em alemão. 